\title{
Changes in the pattern of endometrial protein synthesis during decidualization in the rat
}

\author{
B. Lejeune, R. Lecocq*, F. Lamy* and F. Leroy \\ Human Reproduction Research Unit and ${ }^{*}$ Institute for Interdisciplinary Research, School of \\ Medicine, Free University of Brussels, 1000 Brussels, Belgium
}

\begin{abstract}
Summary. Ovariectomized rats were given hormonal treatment mimicking progestational ovarian secretions. At maximal sensitivity a decidual reaction was induced by scratching the endometrium. After incubation of tissue with $\left[{ }^{35} \mathrm{~S}\right]$ methionine, proteins were extracted from decidualizing and control endometrium and submitted to twodimensional polyacrylamide gel electrophoresis ( $\mathrm{pH}$ range 5-7), followed by staining or autoradiography. A total of about 800 different peptides could be distinguished on the gels. By $24 \mathrm{~h}$ after the decidual stimulus the most prominent changes were the appearance of 4 new peptides (mol. wt 12 000, 25000,42000 and 56000 ) and the disappearance of 5 others (mol. wt $31000,35000,100000,110000$ and 140000 ). This new pattern remained grossly unchanged up to $72 \mathrm{~h}$ after decidual induction.
\end{abstract}

\section{Introduction}

At implantation, the endometrium of rodents undergoes a series of morphological and biochemical changes leading to the formation of decidual tissue. This process is characterized by proliferation, hypertrophy and differentiation into epithelioid decidual cells of stromal fibroblasts, while most of the epithelial tissue disappears, leaving only a few contracted glands (Krehbiel, 1937). Biochemically, the decidual cell reaction entails an increase in alkaline phosphatase activity (Finn \& Hinchliffe, 1964), collagen breakdown (Fainstat, 1963) and also increased DNA, RNA and general protein synthesis (Heald, 1976). At least 3 new proteins appear in the uterus during decidualization and concentrations of a number (up to 8 ) of other protidic molecules are simultaneously increased (Denari, Germino \& Rosner, 1976; Umapathysivam \& Jones, 1978; Bell, 1979a, b).

The aim of the present work was to index proteins appearing or disappearing in the endometrium after decidual induction by taking advantage of the resolution power and high sensitivity of bidimensional polyacrylamide gel electrophoresis (O'Farrell, 1975).

\section{Materials and Methods}

Animals and hormonal treatment. The $12 \mathrm{Wistar}$ rats (body weight $150 \mathrm{~g}$ ) were hormonally treated 8 days after bilateral ovariectomy to induce endometrial sensitivity to decidualizing stimuli (for further details see Lejeune, Van Hoeck \& Leroy, 1981). The 4 control animals were killed at the end of hormonal treatment without applying any decidual stimulus. Decidualization was induced in the 8 experimental rats, under general anaesthesia, by longitudinal scratching of uterine horns at maximal sensitivity. These animals were then treated with $3 \mathrm{mg}$ progesterone and $200 \mathrm{ng}$ oestra- 
diol- $17 \beta$ per day to allow development of a maximal decidual cell reaction. The rats were killed by cervical dislocation $24(\mathrm{~N}=4)$ or $72 \mathrm{~h}(\mathrm{~N}=4)$ after the decidual stimulus.

In-vitro labelling of proteins. Immediately after killing the animals, the uterine horns were removed, longitudinally slit and incubated for $2 \mathrm{~h}$ at $37^{\circ} \mathrm{C}$, under $95 \% \mathrm{O}_{2}$ and $5 \% \mathrm{CO}_{2}$ in $2 \mathrm{ml}$ Krebs-Ringer-bicarbonate buffer ( $8 \mathrm{~mm}$-glucose, $1 \mathrm{~g}$ bovine serum albumin (BSA)/1 and [ $\left.{ }^{35} \mathrm{~S}\right]-$ methionine (sp. act. $1100 \mathrm{Ci} / \mathrm{mmol}$ : Radiochemical Centre, Amersham, U.K.) at $50 \mu \mathrm{Ci} / \mathrm{ml}$ ).

Sample preparation. After incubation the uterine horns were rapidly rinsed 3 times at room temperature in the incubation medium devoid of radioactive tracer. Separation of the endometrium was effected by gentle scraping. The following procedure was applied by $1 \mathrm{mg}$ (wet weight) of tissue. The endometrium or decidua was homogenized in small glass grinders containing $20 \mu 11 \%$ sodium dodecylsulphate (SDS) and 10\% 2-mercaptoethanol in 8 M-urea. After homogenization, $7 \mu \mathrm{l}$ of a mixture of $4 \mathrm{ml} \mathrm{10 \% (w/v)} \mathrm{Nonidet} \mathbf{P}_{40}$ plus $0.32 \mathrm{ml}$ Servalyte pH 5-7 (Serva,

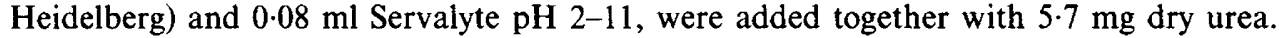

The grinders were rinsed with $28 \mu \mathrm{l}$ lysis buffer (O'Farrell, 1975). The rinse was combined with the homogenate which was centrifuged at $20^{\circ} \mathrm{C}$ in microfuge tubes at $80000 \mathrm{~g}$ for $1 \mathrm{~h}$ (Murthy \& Bharucha, 1978). Each gel was loaded with $50 \mu$ l of the supernatant which contained about 500000 d.p.m. of incorporated specific activity.

Measurements of radioactivity. A $10 \mu \mathrm{l}$ volume of the final homogenate was supplemented with 1 $\mathrm{ml}$ water containing $10 \mathrm{mg} \mathrm{BSA}$ as carrier protein. Proteins were precipitated at room temperature by $1 \mathrm{ml} \mathrm{10 \%}$ trichloracetic acid (TCA). The precipitates were successively washed by $2 \mathrm{ml}$ of the following solutions: $5 \% \mathrm{TCA}$ at room temperature, $5 \% \mathrm{TCA}$ at $95^{\circ} \mathrm{C}$, methanol at room temperature, a mixture of methanol, chloroform and diethyl ether $(2: 1: 2$ by vol.) at room temperature and finally diethyl ether at room temperature. After drying, the protein precipitates were dissolved in 1 $\mathrm{ml}$ Lumasolve (Lumac, Basel). Before counting of radioactivity in a Nuclear Chicago Scintillation Spectrophotometer, $10 \mathrm{ml}$ Lipoluma (Lumac) were added.

Electrophoresis. Two-dimensional gel electrophoresis was performed according to the method described by O'Farrell (1975) except that Servalyte pH 5-7 and 2-11 were used instead of Ampholine with $\mathrm{pH}$ ranges 5-8 and 3-10. Proteins were separated by isoelectric focussing on cylindrical gels in the first dimension ( $\mathrm{pH}$ range 5-7) and according to molecular weight on an SDS linear gradient $(7-17 \%)$ in polyacrylamide slab gels (total length of the separation gel, $22 \mathrm{~cm}$ ) in the second dimension. Measurement of the $\mathrm{pH}$ gradient was performed according to O'Farrell (1975). In some cases, gels were stained with Coomassie brilliant blue G250 (Blaskesley \& Boezi, 1977). Fluorography was carried out according to the instructions given by the New England Nuclear Corporation (Boston, Massachusetts, U.S.A.) using an autoradiographic enhancer. Gels were dried (Biorad gel dryer, model 224) and exposed on X-ray films (Kodak XR-5) for a period of 8 days which was the time calculated to give a total of $4 \times 10^{6}$ d.p.m. per day.

Molecular weights of standard proteins were plotted against polyacrylamide concentration using a bilogarithmic representation as suggested by Lambin, Rochu \& Fine (1976). A linear relationship was obtained for the whole molecular weight range except for the lowest value (i.e. cytochrome C). This reference scale permitted estimates of the molecular weight of any particular peptide revealed on two-dimensional slabs.

\section{Results}

When proteins were extracted from decidual tissue at $72 \mathrm{~h}$ after induction, about 350 protein spots of molecular weight 10000 to 300000 were identified (PI. 1, Fig. 1). When decidualizing tissue was incubated with $\left.{ }^{35} \mathrm{~S}\right]$ methionine about 800 peptides could be detected; the weakest of these spots are not visible on the photographs (Pl. 2, Figs 2, $3 \& 4$ ).

Almost all the loci revealed by staining (Pl. 1, Fig. 1) could also be identified on the corresponding autoradiographs (Pl. 2, Figs 2-4). There were, however, 400 additional spots on the autoradiographs because of their much higher sensitivity. 


\section{PLATE 1}

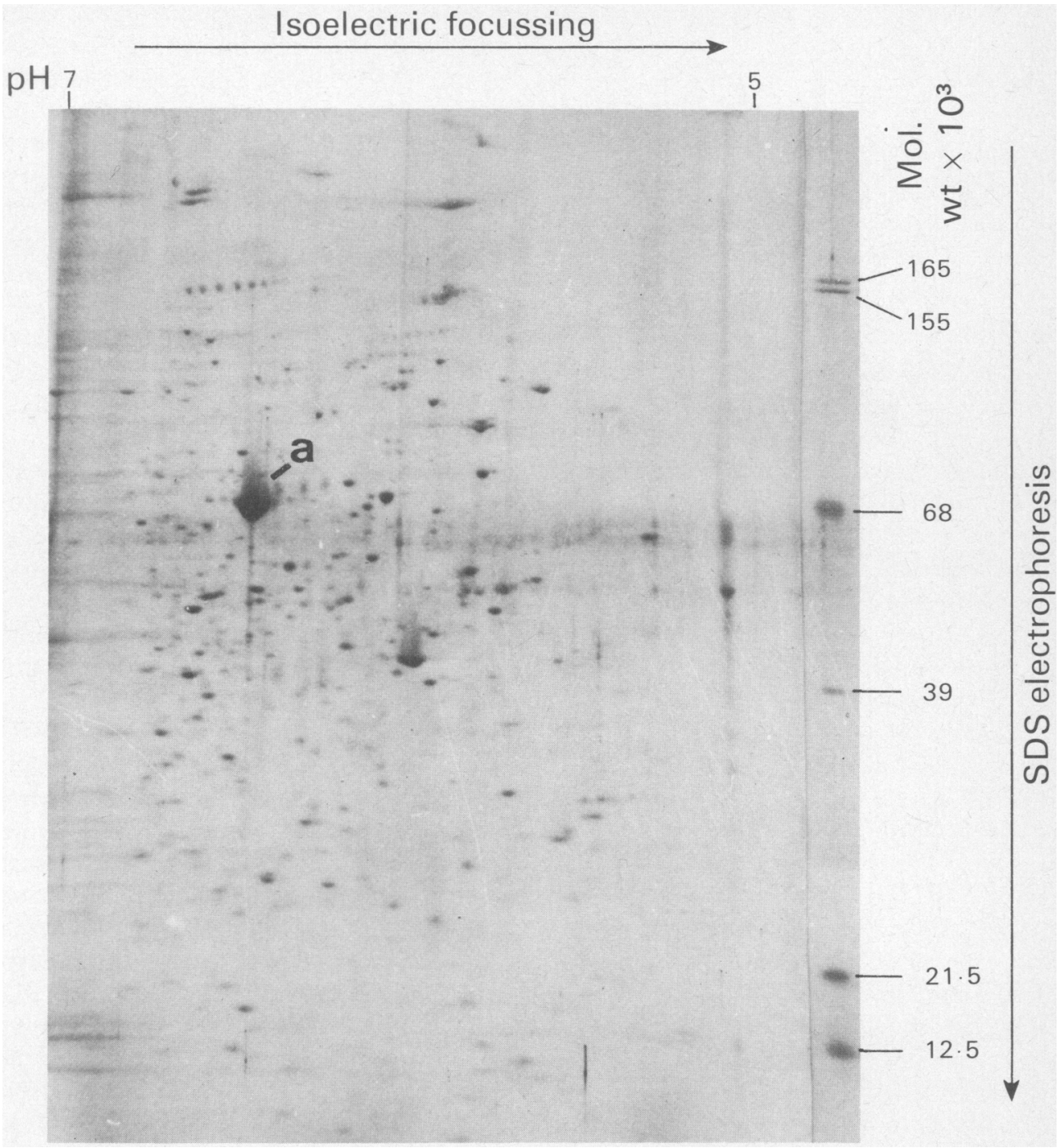

Fig. 1. Two-dimensional electrophoretic separation of proteins extracted from decidual tissue $72 \mathrm{~h}$ after induction. Staining was effected with Coomassie blue G 250 . On the right are the molecular weight standards discriminated in the SDS gel dimension: $E$. coli RNA polymerase ( 39000,155000 and 165000 for $\alpha, \beta$ and $\beta^{\prime}$ subunits, respectively); BSA (68 000); soyabean trypsin inhibitor (2I 500); and cytochrome C (12500). a, bovine serum albumin. 
PLATE 2

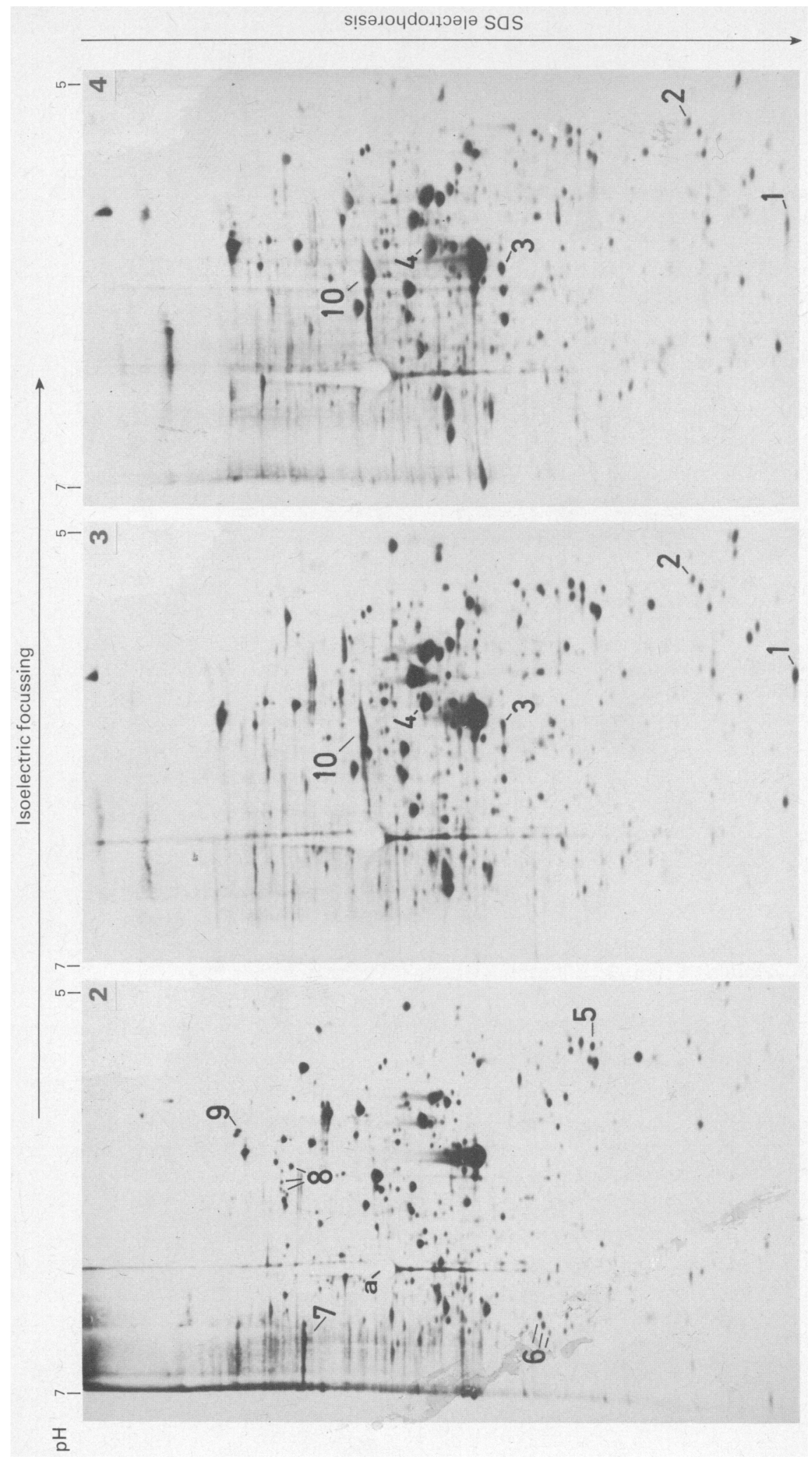


One major peptide visible on the stained gel corresponded to an unlabelled area on the autoradiogram (zone a, Pl. 2, Fig. 2). In other experiments in which BSA was omitted from the incubation medium this stained spot and the corresponding autoradiographic blank had disappeared, suggesting that BSA excludes less abundant labelled polypeptides occupying the same position.

The comparison of autoradiograms corresponding to control endometrium (Pl. 2, Fig. 2) with those obtained from decidualizing tissue at 24 or $72 \mathrm{~h}$ after induction (Pl. 2, Figs $3 \& 4$, respectively) shows reproducible differences, although most of the ${ }^{35} \mathrm{~S}$-labelled peptides are common to the three conditions. Decidualization enhanced the synthesis of several proteins, the most prominent being numbered from 1 to 4 on Pl. 2, Fig. 3 (mol. wt $12000 ; 25000 ; 42000 ; 56000$ ). Some peptides that were visible on the control autoradiogram were no longer synthesized after decidual induction (the main ones are numbered from 5 to 9 on Pl. 2, Fig. 2) (mol. wt $31000 ; 35000 ; 100000 ; 110000$; $140000)$.

A complex situation existed in area 10 (Pl. 2, Fig. 3) where some peptides seemed to have vanished while another (mol. wt 70000 ) seemingly appeared or at least was modified in a way that gave rise to some smearing on the gel. This effect was observed in all the experiments and could be due to glycosylation or other charge changes.

These prominent effects of decidual induction were observed at 24 and $72 \mathrm{~h}$ after scratching the uterine horns. There was no major difference between autoradiographic patterns (Pl. 2, Figs 3 \& 4) obtained at those two intervals.

\section{Discussion}

Two-dimensional polyacrylamide gel electrophoresis isolated about 800 peptides from endometrial and decidual tissues instead of the 25 protein bands which are revealed after one-dimensional migration. Very little tissue is needed for this method and all metabolic processes are stopped at the end of incubation by the addition of SDS, mercaptoethanol and $8 \mathrm{M}$-urea.

In a first step of the process the $\mathrm{pH}$ range was 5-7 and the isoelectric values of about $70 \%$ of the eukaryotic proteins are represented in this range. Experiments are in progress to investigate basic and acidic proteins beyond this range.

In these experiments, in-vitro incubation was preferred for two reasons. It prevents incorporation of the radioactive tracer into plasma proteins which could account for non-specific changes of the protidic patterns. It is also permits higher incorporation of the label into the decidualizing tissue. Pilot experiments in which $\left[{ }^{35} S\right]$ methionine was instilled into the uterine lumen showed that only weak labelling of endometrial proteins occurred in these conditions. Also, little radioactivity was recovered in the supernatant after protein precipitation, suggesting that most of the isotope injected in aqueous solution was rapidly cleared from the uterus. This observation is consistent with the data published by Conner \& Miller (1973) who showed that substances soluble in water disappear in about 30 min after injection into uterine horns, in spite of a double ligature preventing reflux.

\section{PLATE 2}

Autoradiographic patterns of two-dimensional electrophoretic separation of $\left[{ }^{35}\right.$ S $]$ methioninelabelled proteins extracted from rat endometrium.

Fig. 2. Progesterone-dominated endometrium from controls. numbers 5-9 correspond to proteins no longer detected in decidualizing tissue (numbers 6 and 8 are three polypeptides located in the same area); a, bovine serum albumin.

Fig. 3. Endometrium from animals killed $24 \mathrm{~h}$ after decidual induction. Numbers $1-4$ and possibly 10 indicate newly synthesized proteins.

Fig. 4. Decidual tissue from animals killed $72 \mathrm{~h}$ after induction. Numbers $1-4$ and possibly 10 indicate newly synthesized proteins. 
Our present results indicate that by $24 \mathrm{~h}$ after applying the decidual stimulus, i.e. before many decidual cells become conspicuous (Krehbiel, 1937), the synthesis of various peptides has already been stimulated (mol. wt $12000 ; 25000 ; 42000$ and 56000 ). At the same time, the production of several other proteins seems to have ceased (mol. wt $31000 ; 35000 ; 100000 ; 140000$ ). The appearance of newly synthesized proteins during the decidual cell reaction is probably related to differentiation of stromal cells, while the suppression of other peptides could correspond to decidual differentiation or to the involution of epithelial components or to both these mechanisms. Further experiments on separated endometrial tissues might permit resolution of these possibilities.

By using a rabbit antiserum against crude rat deciduoma in double diffusion analysis, Yoshinaga (1973) showed that decidual tissue contains at least 7 specific antigens. Our two-dimensional electrophoresis distinguished only 4 newly synthesized peptides in the decidualizing endometrium. Therefore, some of the antigenic proteins contained in deciduomas might belong to the acidic or the basic $\mathrm{pH}$ ranges which we did not study, or their concentration might be too low to allow electrophoretic detection under the conditions we used.

One-dimensional electrophoretic methods have already shown that decidualization entails an increased concentration of several proteins. Umapathysivam \& Jones (1978) reported 2 proteins (mol. wt 100000 and 49000 ) at $72 \mathrm{~h}$ after decidual induction and Bell (1979a) found increased synthesis of two peptides, one of $140000 \mathrm{~mol}$. wt, detected as early as Day 2 and rapidly increased on Days 4 and 5 and the other of $40000-42000 \mathrm{~mol}$. wt which also reached a maximal synthesis rate on Day 5. Denari et al. (1976) first reported a higher concentration of a protein fraction with electrophoretic properties similar to those of 'oestrogen-induced' protein, occurring as early as $1 \mathrm{~h}$ after decidual induction. Bell, Hamer \& Heald (1980) confirmed the presence of a peptide with electrophoretic mobility equivalent to that of the oestrogen-induced protein at $24 \mathrm{~h}$ after applying a decidual stimulus. The molecular weight of this protein has been estimated at $45000-46000$ (Manak et al., 1980).

Although easy distinction of the reference proteins of 155000 and $165000 \mathrm{~mol}$. wt indicated good separation of proteins in this range, increased synthesis of high molecular weight peptides was not observed in our material. It is possible that the use of $8 \mathrm{M}$-urea and mercaptoethanol was responsible for this result, by preventing di- and tetrameric association. On the other hand, peptides of molecular weight 49000 (Umapathysivam \& Jones, 1978), 42000 (Bell, 1979a) and the oestrogen-induced protein (45000) described by Denari et al. (1976) and Bell et al. (1980), may correspond to peptide 3 (mol. wt 42000 ) in the present work. The absence of the high molecular weight peptide described by Bell $(1979 \mathrm{~b})$ as the 'decidualization-associated protein' may be explained by a different timing in the experimental schedule. Antimesometrial and mesometrial decidual tissues undergo different morphological and temporal patterns of development. The formation of antimesometrial decidua, which entails production of polyploid cells, occurs first and reaches its peak $96-120 \mathrm{~h}$ after decidual induction. Very little differentiation of mesometrial decidua is observed until Day 3 and maximal development in this region is not observed before Days 7-9. The decidualization-associated protein, which seems to be associated with this latter process, becomes prominent after $72 \mathrm{~h}$. The oestrogen-induced protein, which is thought to be associated with cell division (Bell et al., 1980), is detected in the antimesometrial region during the first phase of the decidual cell reaction (Denari et al., 1976). Our experiments have investigated only the first part of the decidual cell reaction and were therefore probably too early to detect large amounts of decidualization-associated protein.

This work was supported by a grant from the Belgian F.R.S.M. and a grant from the Ministry of Scientific Policy ("Actions concertees"). F.L. is "Maitre de Recherches" at the Belgian F.N.R.S. 


\section{References}

Bell, S.C. (1979a) Protein synthesis during decidua morphogenesis in the rat. Biol. Reprod. 20, 811-821.

Bell, S.C. (1979b) Synthesis of decidualization-associated protein in tissues of the rat uterus and placenta during pregnancy. J. Reprod. Fert. 56, 255-262.

Bell, S.C., Hamer, J. \& Heald, P.J. (1980) Induced protein and deciduoma formation in rat uterus. Biol. Reprod. 23, 935-940.

Blaskesley, R.W. \& Boezi, J.A. (1977) A new staining technique for proteins in polyacrylamide gels using Coomassie Brilliant Blue G 250. Analyt. Biochem. 82, $580-582$.

Conner, E.A. \& Miller, J.W. (1973) The distribution of selected substances into rat luminal fluid. J. Pharm. exp. Ther. 184, 291-298.

Denari, J.H., Germino, N.I. \& Rosner, J.M. (1976) Early synthesis of uterine proteins after a decidual stimulus in the pseudopregnant rat. Biol. Reprod. 15, 1-8.

Fainstat, R. (1963) Extracellular studies of the uterus. Disappearance of the discrete collagen bundles in endometrial stroma during various reproductive states in the rat. Am. J. Anat. 112, 337-369.

Finn, C.A. \& Hinchlifie, J.R. (1964) The reaction of the mouse uterus during implantation or deciduomata formation as demonstrated by changes in the distribution of alkaline phosphatase. J. Reprod. Fert. 8 , 331-338.

Heald, P.J. (1976) Biochemical aspects of implantation. J. Reprod. Fert., Suppl. 25, 331-338.
Krehbiel, R.H. (1937) Cytological studies of the decidual reaction in the rat during early pregnancy and in the production of deciduomata. Physiol. Zool. 10, 212234.

Lambin, P., Rochu, D. \& Fine, J.M. (1976) A new method for determination of molecular weights of proteins by electrophoresis across a SDS polyacrylamide gradient gel. Analyt. Biochem. 74, 567-575.

Lejeune, B., Van Hoeck, J. \& Leroy, F. (1981) Transmitter role of the luminal uterine epithelium in the induction of decidualization in rats. J. Reprod. Fert. 61, 235-240.

Manak, R., Wertz, N., Slabaugh, M., Denari, H., Wang, J.-T., \& Gorski, J. (1980) Purification and characterization of the oestrogen-induced protein (I.P.) of the rat uterus. Molec. cell. Endocr. 17, 119-132.

Murthy, M.R.V. \& Bharucha, A.D. (1978) Ultracentrifugation of small volumes of tissues extracts without the use of tube adaptors. Analyt. Biochem. 85, 251254.

O'Farrell, P.H. (1975) High resolution two-dimensional electrophoresis of proteins. J. biol. Chem. 250, 40074021 .

Umapathysivam, K. \& Jones, W.R. (1978) An investigation of decidual specific proteins in the rat. Int. $J$. Fert. 23, 138-142.

Yoshinaga, K. (1973) Antigens specific to the decidual tissue. Biol. Reprod. 9, 99, Abstr.

Received 28 January 1982 